\title{
PENGARUH POLITIK LUAR NEGERI TERHADAP STRUKTUR MASYARAKAT HUKUM INTERNASIONAL DAN PARADIGMA HUKUM POSITIF BERKEMANUSIAAN
}

\author{
Mohammad Ridwan ${ }^{1}$
}

\begin{abstract}
Abstrak
Dalam perspektif sosiologi hukum internasional, dengan pendekatan critical legal studies dan sociological jurisprudence (seperti Behavior of Law dari Donald Black), ternyata bisa ditemukan kebenaran artikulatif yang terbentuk oleh kepentingankepentingan politik yang dipaksakan secara internasional, sehingga membentuk kebenaran salah kaprah yang kemudian menjadi kebenaran normatif. Perilaku politik predominan negara dalam ranah internasional, memerlukan pengembangan hukum politik yang imperatif; dan ini memerlukan kesungguhan itikad baik politik negara adidaya (yang muskil terjadi).
\end{abstract}

Kata kunci: Sosiologi Hukum Internasional, Critical Legal Study, Sociological Jurisprudence, Hukum Politik.

\begin{abstract}
Critical Legal Studies and Sociological Jurisprudence Approaches (like Donald Black's 'The Behavior of law') In the international sociology of law perspective, has been found articulate truth that has been articulated from international impressed of political interests. This recent situation is forming fallacious truth, and than to be normative truth. Political behavior of predominant State in international scope needs to promote imperative political law, and it needs sincerity of political will of super power State (and it is won't to be done).
\end{abstract}

Keywords: Sociology of International Law, Critical Legal Study, Sociological Jurisprudence, Political Law.

1 Lektor Kepala dalam Hukum Internasional di FH UNIBRAW. Alamat kontak: nawdir53@gmail.com. 


\section{Pendahuluan}

Invasi ke Irak dan dilegitimasinya pendudukan oleh Amerika Serikat beserta segenap sekutunya terhadap negara Irak beberapa tahun lalu, saat itu telah menimbulkan kerancuan berbagai komentar dari para penstudi Hukum Internasional. Banyak pihak mengkhawatirkan kecenderungan tindakan unilateral Amerika Serikat dan para sekutunya, karena dipandang potensial mengancam masa depan rule of law dalam hubungan internasional. Bila, dengan berbagai alasan, tindakan unilateral mendapatkan legitimasi, lalu bagaimanakah perwujudan Hukum Internasional mendatang? Apakah memang sesungguhnya Hukum Internasional hanya menjadi alat kekuasaan belaka?" Barangkali jawabnya adalah "ya" jika tidak ada central power dalam tatanan kehidupan antar negara ini. Namun demikian, apabila ada central power dalam hubungan antar negara, maka tidak ada lagi istilah Hukum Internasional sebagaimana Mochtar Kusumaatmadja katakan, melainkan Hukum Dunia. Terlepas dari polemik sirkulair demikian ini, perbincangan tentang Hukum Internasional menjadi menarik tatkala difokuskan kepada cara pandang dan analisis.

\section{Pandangan Hukum Critical Legal Studies}

Bagi kaum Critical Legal Studies, makna hukum, doktrin hukum, dan kebenaran hukum hanyalah konstruksi sosial yang berkait erat dengan politik dan dihasilkan oleh proses dialectical truth, karena itu selalu memiliki nilai relatif sesuai konteks sosial yang melatarbelakanginya. Apabila hukum dipandang sebagai bagian dari politik, maka akan terlihat sebagai sebuah hubungan kekuatan. Kaum Critical Legal Studies memang adalah kaum gerakan yang tidak puas terhadap kenyataaankenyataan perlakuan para pengambil kebijakan terhadap hukum. Jikalau kenetralan, keobyektifan, dan nilai universal hukum diperlakukan semestinya oleh pelaksana dan legislator, maka bukan mustahil kaum Critical Legal Studies tidak akan muncul, atau kemunculannya disebabkan oleh alasan dan motivasi yang berbeda.

Ketidakpuasan terhadap hukum yang sedang dijalankan, tidak hanya muncul dari kaum Critical Legal Studies, jauh sebelum itu para sosiolog atau para ahli hukum yang mengubah diri menjadi sosiolog hukum menyoroti hukum sebagaimana yang mereka kritisi. Contohnya, Max Weber, Karl Marx, Emile Durkheim, dan lainlainnya melihat hukum dari sisi-sisi tertentu dengan mengatakan, bahwa hukum itu

${ }^{2}$ Lihat pandangan Hans Morgenthau, "Politics Among Nations: The Struggle for Power and Peace”, (Boston: McGraw-Hill Book, 1993), hal. 253-265. 
adalah gejala masyarakat dalam bidang tertentu. Misalnya, di bidang ketimpangan ekonomi, di bidang kesenjangan sosial, di bidang deviasi perilaku politik, dan sebagainya. Kaum Critical Legal Studies lebih bebas lagi melihat hukum sebagaimana yang ingin dikritiknya.

Harus diakui, bahwa manakala hukum dipandang sebagai produk politik, maka hukum yang demikian adalah hasil bargaining politik para pihak yang dinyatakan memiliki otorita legislasi. Jikalau dikatakan, bahwa hukum adalah produk dinamika sosial/budaya, maka bisa dipastikan, bahwa hukum demikian adalah hasil responsi terhadap kebutuhan-kebutuhan sosial dan bentukan-bentukan budaya. Dengan demikian, maka hukumpun dipandang sebagai obyek kajian kontekstual.

Manakala hukum dikaji secara kontekstual dengan habitat hukum itu berada, maka Donald Black dalam karyanya yang dikategorikan dalam Sociological Jurisprudence, ${ }^{3}$ menjadi alat analisis yang sesuai dengan kecenderungankecenderungan hukum dalam masyarakat.

Bagi Black hukum adalah kendali sosial pemerintah. Pandangan demikian ini identik dengan para pemikir sosiologi lainnya seperti Radcliffe-Brow, Roscoe Pound, ataupun Redfield. Apabila cara pandang ini diikuti dan diterapkan dalam situasi internasional, maka Hukum Internasional akan terlihat sebagai pergulatan kepentingan-kepentingan politik masing-masing negara. Dengan demikian bisa terlihat, bahwa Hukum Internasional sebenarnya berawal dari hukum nasional untuk urusan luar negeri. Kalaulah hukum nasional dianggap sebagai produk peradaban sebuah bangsa, yang nota bene adalah produk budaya, maka kebijakan-kebijakan luar negeri suatu negara yang bisa memberi jiwa (substansi) kepada hukum yang terbentuk, akan berpengaruh besar kepada perjanjian-perjanjian bilateral maupun multilateral antar bangsa. Melalui cara demikian, Hukum Internasional bisa berupa bagian dari produk peradaban negara-negara. Dalam peta situasi internasional seperti ini, kekuatan tolak-tarik yang terdapat dalam persinggungan antar budaya ini cukup berperan. ${ }^{4}$ Hasil akhir pergulatan budaya dalam situasi ini akan menimbulkan suatu kondisi predominan suatu budaya tertentu.

Tidak mengherankan, bahwa Hukum Internasional modern berwujud suatu konstruksi sosial internasional yang lahir dari suatu kondisi budaya hegemoni. ${ }^{5}$

${ }^{3}$ Donald Black, "Behavior of Law", (London: Academic Press, 1976), tanpa nomor halaman.

${ }^{4}$ Deborah Z Cass, Navigating the Newstream: Recent Critical Scholarship in International Law, Nordic Journal of International Law, No.65, Kluwer, The Hague, 1996, hal. 349. 
Penguasaan kebudayaan bukan mustahil terjadi dengan berbagai cara. Salah satunya adalah dengan cara infiltrasi budaya. Cara ini bisa melalui unsur musik, dressfashion, hair style, macam makanan dan table mannernya, studi ke luar negeri, transfer Ilmu dan Pengetahuan, dan sebagainya. Semua unsur itu mempengaruhi sikap dan perilaku yang kemudian membentuk pola budaya tertentu di suatu negara. Akibat dari itu, budaya asal akan tererosi dan kemudian lenyap.

\section{Kebenaran Artikulatif}

Dalam konteks kebenaran hukum (legal truth), sosok Hukum Internasional yang tersusun baik dalam perjanjian bilateral maupun multilateral, adalah sebagai kebenaran normatif. Sementara itu Dialectical Truth atau kebenaran dialektik tidak lepas dari hubungan-hubungan kekuatan. Jika demikian, maka negara-negara yang memiliki segala potensi kekuatan akan berhasil melakukan kendali yang cukup bermakna (signifikan) terhadap "kebenaran" normatif itu.

Sampai dengan saat ini, konsep-konsep Hukum Internasional yang ada merupakan refleksi atau pengalihan nilai dan kepentingan-kepentingan Barat. ${ }^{6}$ Sehubungan dengan itu, bagi negara yang menganggap Hukum Internasional bagian dari Hukum Nasionalnya, bukannya Hukum Internasional yang berpengaruh terhadap Hukum Nasionalnya, namun sebaliknya Hukum Nasionalnya mempengaruhi Hukum Internasional. Berkaitan dengan situasi seperti ini, "kebenaran" hukum dari negara tertentu yang mendominasi hubungan-hubungan bilateral ataupun multilateral akan merambat secara penetratif ke dalam negaranegara yang terdominasi. Dengan cara ini sebuah atau lebih negara, sadar atau tidak sadar, mau ataupun tidak mau, akan terpengaruh dengan "kebenaran" hukum dari negara dominan itu. Contoh: Penyerbuan kolektif ke Irak oleh Amerika Serikat dan para sekutunya, sebagaimana awal tulisan ini, didasarkan atas "kebenaran" baru yang diperkenalkan oleh Presiden Amerika serikat yang dikenal dengan pre-emptive action. Padahal doktrin hukum terdahulu menyatakan, bahwa keabsahan tindakan penyerbuan dikarenakan adanya bukti positif perbuatan pelanggaran hukum. Keabsahan tindakan penyerbuan itu merupakan sanksi karena adanya pelanggaran hukum yang nyata-nyata telah terjadi. Contohnya, karena Irak melakukan invasi ke

5 J. Graig Barker, "International Law and International Relation”, (London: Continuum, 2000), hal. 92.

${ }^{6}$ Martti Koskenniemi, "From Apology to Utopia: The Structure of International Legal Argument", (Helsinski: Lakimiesliton Kustannus, 1989), h.xxiii. 
Kuwait, yang berarti Irak nyata melakukan pelanggaran hukum, maka Irak diberi sanksi oleh masyarakat Internasional melalui resolusi Dewan Keamanan PBB. Dengan demikian, maka penyerbuan terhadap Irak, yang bertujuan agar Irak keluar dari Kuwait, mendapatkan keabsahan yuridis. Doktrin baru dari Amerika Serikat ini (pre-emptive action) ibarat orang melihat ular, dengan prasangka buruk (bad faith) ularpun dibunuh. Serupa dengan itu, Irak secara buruk dikira (atau diciptakan suatu kesan) akan atau sedang melakukan perbuatan pelanggaraan hukum; karena itu Irak harus dihancurkan lebih dahulu supaya tidak akan bisa melakukan perbuatan buruk. Secara umum prasangka buruk itu terlarang, karena itu secara umum presumption of innocence menjadi sebuah asas dalam hukum acara. Akan tetapi Amerika Serikat mampu membuat "kebenaran" sebaliknya: prasangka buruk itu menjadi boleh asalkan alasan-alasan untuk berprasangka buruk itu bisa diyakinkan (bukan dibuktikan). Sampai sekarang tidak pernah terbukti secara hukum alasan-alasan Amerika Serikat sebagai dasar penyerbuan terhadap Irak itu. Tapi anehnya sampai sekarang pula masyarakat internasional tetap tidak mengganggugugat terhadap "doktrin baru" itu. Inilah kebenaran artikulatif yang bisa dilakukan dalam gunman situation. Kalau mau jujur, sesungguhnya masyarakat internasional telah berkhianat terhadap seluruh tujuan dan asas-asas Perserikatan Bangsa Bangsa. Sepakatnya Dewan Keamanan untuk membiarkan Amerika Serikat membuktikan, bahwa Irak telah potensial merusak dunia dengan senjata nuklir berdasarkan pasal 50 Piagam Perserikatan Bangsa- Bangsa, adalah sangat keterlaluan. Pasal 50 itu persyaratan preventive action, bukannya pre-emptive action. Kedua istilah itu sangat jauh maknanya. Preventive action adalah upaya pencegahan tanpa pelanggaran hukum, sedangkan pre-emptive action adalah upaya tindakan penyerangan atau menduduki lebih dahulu, dalam hal ini cara bertindak yang dilakukan oleh Amerika Serikat dengan menghancurkan sistem politik, ketatanegaraan, tata pemerintahan, sistem sosial, kebudayaan, sekaligus ekonomi sebuah bangsa yang merdeka dan berdaulat. Jelas sekali pre-emptive action adalah tindakan pelanggaran hukum.

\section{Hukum dan Politik}

Dalam ranah publik, hukum bersentuhan dengan bentuk kegiatan publik lainnya, yaitu politik. Berkenaan dengan pembicaraan yang tersebut di atas, hukum dan politik bisa dipastikan tidak akan bisa dipisahkan satu sama lain. Di bidang hubungan internasional ada saling ketergantungan yang sangat dan hampir tidak bisa dipisahkan: politik internasional adalah dan menjadi hukum internasional sembari 
hukum internasional adalah dan menjadi politik internasional ${ }^{7}$. Manakala kenyataan demikian ini mendapat tempat dalam cara berpikir, maka bukan mustahil jalinan berkelindan antara hukum dan politik ini akan saling bertumpang tindih. Apabila jalinan berkelindan yang saling tumpang tindih ini hendak dicoba untuk diunggulkan salah satunya, maka penonjolan aspek politik akan terutamakan. Contoh: tatkala issue terorisme yang dilempar oleh Amerika Serikat mengkristal menjadi Konvensi Anti-Terorisme, maka dengan langkah-langkah politik serupa, Amerika Serikat beserta sekutunya memprovokasi negara-negara lain agar membentuk UndangUndang Nasional Anti-Terorisme. Tema utamanya berpedoman pada prinsip "preemptive action". Prinsip perang inilah yang dipakai oleh George W. Bush dalam dunia damai. Padahal menurut piagam Perserikatan Bangsa-Bangsa (PBB), untuk mencapai tujuan-tujuan, maka PBB menyerukan: ${ }^{8}$

- to practice tolerance and live together in peace with one another as good neighbors, and

- to unite our strength to maintain international peace and security, and

- to ensure by the acceptance of principles and the institution of methods, that armed force shall not be used, save in the common interest, and

- to employ international machinary for the promotion of the economic and social advancement of all peoples.

Jelas sekali, bahwa doktrin Bush "pre-emptive action (attack)" itu bertentangan dengan cara-cara PBB mencapai tujuannya. Namun rupanya dalih doktrin ini berdasar pada to unite our strength to maintain international peace and security, Jadi dalam memelihara perdamaian dan keamanan internasional, maka menurut doktrin ini perlu menyatukan kekuatan. "Gejala" penggangguan terhadap Perdamaian dan Keamanan Internasional terdeteksi dengan adanya langkah-langkah politik yang dilakukan oleh Irak yang tidak "menyamankan" Amerika Serikat. Karena rancangan politik global Amerika Serikat di Timur Tengah berkemungkinan terganggu, sebelum hal itu terjadi, maka Amerika Serikat membuat manuver politik internasionalnya dengan cara melibatkan hukum internasional. Di sinilah jalinan berkelindan antara hukum dan politik internasional terajut. Dengan doktrin "preemptive action (attack)" yang dijadikan principle, maka tercetuslah resolusi-resolusi

\footnotetext{
${ }^{7}$ Francis Anthony Boyle, "World Politics And International Law", (Durham: Duke University Press, 1985), hal. 81.

${ }^{8}$ Charter of the UN and Statute of the ICJ, Department of Public Information, UN, New York.
} 
baik dari Majelis Umum maupun Dewan Keamanan PBB guna keabsahan penyerbuan ke Irak.

Semestinya, penyelesaian secara damai harus dilakukan dan diupayakan sedapat mungkin melalui berbagai macam cara sebagaimana adanya dalam bab VI Piagam PBB. Namun rupanya, secara politik Amerika Serikat menghendaki sebaiknya bab VII Piagam PBB itulah yang perlu diperlakukan terhadap Irak agar Amerika Serikat bisa mengendalikan urusan dalam negeri Irak apabila negara ini sudah kehilangan kendali pemerintahannya.

Dalam rangka penguasaan terhadap Irak itulah Amerika Serikat melakukan manuver-manuver canggih. Betapa tidak! Amerika Serikat menjalankan apa yang disebut oleh Donald Black dalam proposisinya tentang perilaku hukum, yang menyatakan, bahwa hukum (dengan asumsi: Law is govermental social control) berkecenderungan berlaku berdasarkan stratifikasi, morfologi, kultur, organisasi, dan kendali sosial ${ }^{9}$. Dalam hal stratifikasi sosial internasional, Irak dikondisikan dalam strata sosial rendah. Dengan begitu, Irak akan terlihat sebagai negara terbelakang. Secara morfologis, Irak diupayakan teralienasi oleh negara-negara Arab lainnya, sehingga tidak ada atau paling tidak kurang interkoneksi dan interdependensi diantara negara Arab. Dari aspek kultur internasional, oleh karena Irak sudah teralienasi, kehilangan interkoneksi dalam dunia Arab, maka iapun menjadi bukan bagian dari kultur internasional. Dalam aspek organisasi tata pergaulan internasional, dengan mengkondisikan Irak dalam situasi internasional seperti tersebut tadi, maka Irak sudah bukan lagi menjadi bagian integral masyarakat internasional yang didominasi oleh Amerika Serikat. Dengan demikian, maka kendali sosial internasional perlakuan terhadap Irak berada pada tangan Amerika Serikat yang predominan terhadap dunia internasional. Dalam seluruh proposisi Donald Black ini, Amerika Serikat mendominasi keuntungan-keuntungan dalam tiap proposisi. Dengan demikian layaklah Amerika Serikat disebut sebagai negara Super Power, baik di bidang sosial internasional, maupun teknologi universal.

Mengingat bahwa dalam kenyataan masyarakat internasional terdapat strukturstruktur kekuatan sosial yang lahir dari struktur kekuatan politik, maka ekses yang timbul adalah hukum internasional pun menjadi tergantung pada struktur politik internasional. Menurut pola demikian, maka perubahan struktur politik internasional akan diikuti dengan perubahan pula pada legalitas, legitimasi, maupun validitas sebuah fakta hukum internasional. Kalaulah begitu, akibatnya politik internasional tidak hanya berfungsi menetapkan hierarkhi (struktur), melainkan juga potensial

\footnotetext{
${ }^{9}$ Lihat supra note 6 .
} 
untuk merubah struktur. Situasi demikian inilah yang dicermati oleh para penyusun strategi politik untuk urusan luar negeri suatu negara.

\section{Hukum Politik}

Kajian Politik Hukum sudah banyak yang mengulas, dan kajian ini menjadi rancu jika terminologinya dibahasa asingkan. Dalam bahasa Inggris misalnya, apakah ia diterjemahkan sebagai Politics of Law, Legal Politics, ataukah Legal Policy? Kalaulah mengikuti bahasa nenek moyangnya pelajaran hukum di Indonesia, politik hukum adalah rechtspolitiek. Tapi ilmu hukum yang dipakai dalam aspek ketatanegaraan adalah ilmu hukum Hans Kelsen. Padahal menurut Hans Kelsen, rechtspolitik itu bukan bagian dari ilmu hukum murni, melainkan pembicaraan di luar ilmu hukum murni dari Kelsen. Jadi ada bias dalam cara berpikir kaum penstudi ilmu hukum di Indonesia. Ada semacam ilmu hukum ecclesiastical di Indonesia ataukah ilmu hukum inconsistence? Yang saya maksud dengan ecclesiastical (berasal dari kata Yunani: ekklesiasticos; ekklesia yang berarti assembly) adalah ilmu hukum "campuran" atau "campur aduk"; sedangkan yang saya maksud dengan inconsistence adalah "tidak taat asas". Betapa tidak! Dikatakan ilmu hukum "campur aduk" atau inconsistence atau "tidak taat asas" karena hukum tata negara kita jelas sekali memakai teori dari Hans Kelsen (yang jelas-jelas menolak keberadaan politik hukum sebagai bagian dari ilmu hukum Hans Kelsen), tetapi dalam studi ilmu hukum di fakultas-fakultas hukum diajarkan politik hukum sebagai bagian dari ilmu hukum. Apa tidak "campur aduk" atau inconsistence atau "tidak taat asas" sebagai ganti kata "rancu"?

Bahasan kali ini tidak tentang politik hukum, melainkan hukum politik, yaitu bicara tentang bagaimana kebutuhan dan kepentingan masyarakat diproteksi secara hukum. Dalam dimensi ini, politik dalam bentuk pengusahaan kepentingan (the efforts of interests) menjadi obyek pemikiran substansial oleh hukum.

Guna memahami dasar teoretik pemikiran ini, secara epistemologis perlu lebih dahulu sedikit uraian tentang induk pemahaman dasar teoretik ini, yaitu teori ilmu hukum yang bersentuhan dengan masyarakat bernama Sociological Jurisprudence. Pemahaman ilmu hukum aliran ini is an intrinsically theoretical approach to the study of the law and it specifically seeks to understand law as a particular social phenomenon, in term of how it comes into existence, how it operates and the effects that it has on those to whom it applies. ${ }^{10}$

\footnotetext{
${ }^{10}$ Law Cards, “Jurisprudence”, (London: Cavendish Pub., reprinted 1998), hal. 124.
} 
Walaupun teori ilmu hukum ini melihat hukum sebagai gejala sosial yang khusus, tetapi sangat berbeda dengan Sociology of Law maupun Sociolegal Studies. Sociological Jurisprudence bersifat teoretik-normatif dengan memperhatikan kondisi dan situasi sosial; sedangkan sosiologi hukum (sosiology of law) adalah studi teoretik-empirik terhadap hukum dalam konteks sosial. Adapun kajian-kajian Sosiolegal (Sociolegal Studies) adalah penyelidikan sosial-pragmatik terhadap bekerjanya hukum. ${ }^{11}$ Perbedaan kajian antara Orthodox Jurisprudence, Sociological Jurisprudence, Socio-legal Studies, dan Sociology of Law dapat dibagankan sebagai berikut: ${ }^{12}$

Perbedaan Kajian teori-teori Hukum dan Masyarakat

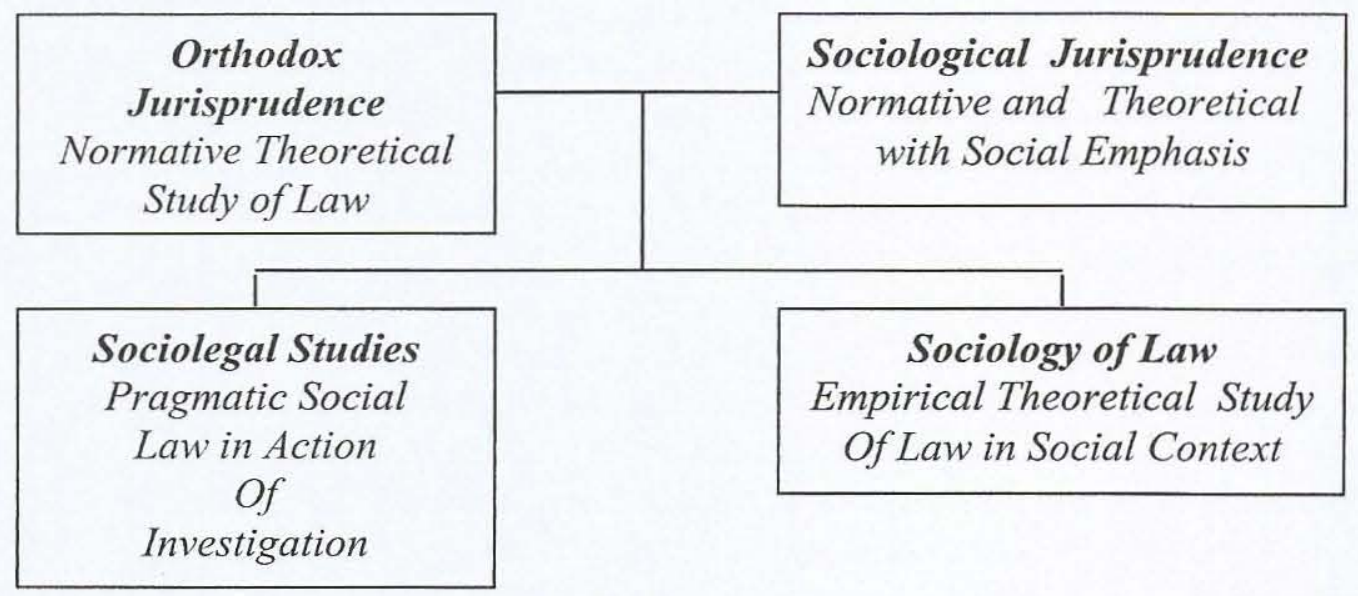

Kajian Sociological Jurisprudence ini melahirkan satu sub kajian yang disebut Jurisprudence of Interests. Pada awalnya Sociological Jurisprudence ini diperkenalkan oleh ahli hukum Jerman bernama Philip Heck, yang kemudian dikembangkan oleh Roscoe Pound di Amerika. ${ }^{13}$ Berdasarkan teori ilmu hukum hasil

"Ibid., hal. 123. Juga Hari Chand, "Modern Jurisprudence", (Kuala Lumpur: International Law Books Services, 1994), hal. 196.

${ }^{12}$ Ibid.

${ }_{13}$ Surya Prakash Sinha, "Jurisprudence, Legal Philosophy In A Nut Shell", (St. Paul, Minnesota: West Pub. Co., 1993), hal. 232. 
pengembangan Roscoe Pound ini, ada beberapa klasifikasi interests yang diproteksi secara hukum, yaitu: ${ }^{14}$

a. public interests, include the interests of the State:

1.in subsistings a State;

2.in acting as a guardians of social interests.

b. individual interest, consist of:

1. interest of personality, such as protection of physical integrity, freedom of will, reputation, privacy, and freedom of belief and opinion;

2. interest of domestic relations, such as protection of marriage, maintenance claims, and legal relations between parents and children;

3. interest of substance, such as protection of property, freedom of testation, freedom of industry, and contract.

c. social interests are composed of interests in:

1. general security;

2. security of social institutions;

3. general morals;

4. protection of social resources from waste;

5. general progress;

6. individual human life.

Dari klasifikasi interest yang diproteksi secara hukum itu ada satu klasifikasi kepentingan umum (public interests) yang berkenaan dengan aktifitas politik kenegaraan, yaitu the interests of the State in subsisting as a State; dan satu lainnya yang berkenaan dengan politik kemasyarakatan, yaitu the interests of the State in acting as a guardian of social interests. Dalam dua sub klasifikasi ini, sesungguhnya adalah persoalan bagaimana mengintegrasikan kebutuhan dan kepentingan publik itu dan bagaimana memproteksinya secara hukum.

Sifat aksiologis hukum politik ini justru terletak pada etik atau moralitas sebagai kandungan esensial hukum yang memproteksi kebutuhan dan kepentingan publik itu. Aktifitas kajian ini adalah terhadap keseimbangan pemberian beban antara hak dan kewajiban dalam hal pemenuhan kebutuhan dan kepentingan publik, kemudian bagaimana pengaturan hak dan kewajiban itu. Dengan demikian

\footnotetext{
${ }^{14}$ Edgar Bodenheimer, "Jurisprudence, The Philosophy and Method of The Law", $3^{\text {rd }}$ printing, (Cambridge, Massachusetts: Harvard University Press, 1970), hal. 111. Juga Surya Prakash Sinha, Op.Cit., hal. 233.
} 
mekanisme ini adalah memasukkan nilai-nilai etik, keseimbangan beban hak dan kewajiban, dan memprediksi akibat hukum-akibat hukum yang timbul (legal effects).

Ilmu hukum ini bukanlah perihal law as a tool for social engineering (garis bawah dari saya). ${ }^{15}$ Bilamana demikian halnya, maka hukum hanyalah sebagai alat penguasa untuk merekayasa masyarakat atau seperti kata Nonet Selznick tersebut di atas, bahwa dalam situasi seperti itu maka law as the servant of repressive power. Mochtar Kusumaatmadja menulisnya tidak keliru, yaitu law as a tool of social engineering. ${ }^{16}$ Jauh sekali maknanya dibandingkan dengan law as a tool for social engineering. Bagi Pound dengan pandangannya itu, substansi hukum adalah bagian dari kerekayasaan (perkembang-tumbuhan secara dinamis) masyarakat, sehingga hukum dan masyarakat itu integratif. ${ }^{17}$ Dengan demikian, maka dalam konteks politiknya, hukum dan politik itu berjalin berkelindan (intertwine), oleh karena substansi hukum yang terkaidahkan itu bersumber kepada kebutuhan dan kepentingan masyarakat.

Berbeda dengan politik hukum yang mempersepsi hukum dari visi politik; kajian ini (yaitu hukum politik), yang bernama political law (bukan the law of politics) adalah kajian tentang hukum yang bernuansa politik, baik yang bersifat nasional maupun yang bersifat internasional. Namun demikian, beranjak dari klasifikasi Pound yang diturunkan dari Heck tentang jurisprudence of interests, sebenarnya public interests bisa dikembangkan tidak saja berskala nasional, tapi bisa berskala internasional atau global. Interests in subsisting (a State) tidak saja berlaku bagi negara dalam kedaulatan internalnya, tetapi juga kedaulatan ekternalnya; bahkan berlaku pula bagi organisasi dan administrasi internasional. Demikian pula halnya dengan interests of the State in acting as guardians of social interets, tidak hanya berlaku bagi social interests dalam kedaulatan internal saja, tetapi juga berlaku bagi social interests berskala internasional atau global. Dengan perkataan lain, dengan mengkonversi skala nasional menjadi skala internasional ataupun global, maka kajian hukum politik ini tidak terbatas pada ketatanegaraan dan

${ }^{15}$ Bernard Arief Sidharta, "Refleksi Tentang Struktur Ilmu Hukum, Sebuah Penelitian Tentang Fundasi Kefilsafatan Dan Sifat Keilmuan Hukum Sebagai Landasan Pengembangan Ilmu Hukumnasional Indonesia", (Bandung: Mandar maju, 2000), hal. 27. Dalam halaman 27 buku itu seharusnya tertulis law as a tool of social engineering.

16 Mochtar Kusumaatmadja, "Fungsi dan Perkembangan Hukum dalam Pembangunan Nasional", (LPHK, FH UNPAD: Binacipta, tanpa tahun), hal. 11.

${ }^{17}$ Hari Chand, Op. Cit., hal. 198. 
ketatapemerintahan nasional saja, tetapi meluas sampai dimensi internasional ataupun global.

Kajian hukum politik ini memiliki sifat dasar keilmuan sebagaimana Jurisprudence of interests itu sendiri. Sifat communal, universal, disinterestedness, dan organized scepticism ada padanya. ${ }^{18}$

Sifat communal, bahwa kajian ini boleh dipelajari oleh semua orang yang menjadi komunitasnya. Bersifat universal, oleh karena kajian ini tidak dibatasi oleh ruang dan waktu. Kajian ini juga tidak mengabdi pada pihak-pihak tertentu atau tanpa pamrih (disinterestedness). Sifat organized scepticism terbukti, bahwa kajian ini memiliki disiplin keilmuan sebagaimana disiplin dasarnya, dan terbuka bagi keraguan-keraguan ilmiah terhadapnya.

Sifat rasionalisme-empirisnya pun sangat jelas. ${ }^{19}$ Dikatakan demikian karena kajian ini adalah kegiatan akal budi mengintegrasikan dan memproteksi (kegiatan etik sekaligus teknik) berdasarkan pengetahuan dan pengalaman manusia terhadap realita empirik (positif) berupa kebutuhan dan kepentingan manusia. Dengan kata lain pada faset ontologis pun kajian ini memenuhi syarat sebagai ilmu.

Hukum politik ini juga mampu menjinakkan dominasi dan arogansi kekuasaan politik dan melunakkan kedaulatan hukum. Dikatakan menjinakkan dominasi dan arogansi kekuasaan politik oleh karena hukum politik ini menyeimbangkan beban hak dan kewajiban antar kebutuhan dan kepentingan politik negara serta membebankan tanggungjawab bagi para pelakunya; ${ }^{20}$ sedangkan dikatakan melunakkan kedaulatan hukum (hukum otonom) oleh karena hukum politik ini bersumber pada kedaulatan rakyat yang dinamik sesuai perkembangan waktu. Dengan perkataan lain hukum politik ini adalah bersifat responsif.

${ }^{18}$ Kuliah Filsafat Ilmu dari Prof Abdulgani, S.H., M.S. di Fakultas Pasca Sarjana UNAIR tgl.14 Oktober 1986.

${ }^{19}$ N. Daldjuni, Hubungan Etika dengan Ilmu, dalam Jujun Suriasumantri (ed.) Ilmu dalam Perspektif, (Jakarta: Gramedia, 1984), hal. 233.

20 Aspek 'tanggungjawab' dalam hubungan hukum diperkenalkan oleh A. Masyhur Effendi, dalam Pidato Pengukuhan Gurubesar beliau di Unibraw, Debat Internasional, Memposisikan Aspek Tanggungjawab dalam HAM, 1993. 


\section{Kegunaan Hukum Politik}

Sampai saat ini, hukum masih dalam paradigma positivisme. Artinya, berdasar pada sensor pancaindra manusia, mengikuti alam kebendaan. Hukum adalah apa yang tertulis, sebagai konsistensi dari kepastian hukum. Hukum dilepaskan dari moral, karena moral bukan bagian dari dunia empiris. Perjanjian-perjanjian berdasar pada apa yang diperjanjikan, sehingga bisa terjadi apa yang menurut moral tidak boleh menjadi boleh dan menurut moral boleh menjadi tidak boleh. Contoh: judi, pelacuran, hubungan seks suka sama suka, pegawai negeri, tentara, polisi ikut berpartisipasi aktif di bidang politik menurut moral tidak boleh, tapi hukum bisa membolehkan. Hukum bisa pula melarang yang dibolehkan moral, misalnya pegawai negeri di Perancis dilarang mengenakan atribut/accesories keagamaan dalam hal berpakaian (jilbab, kalung salib dan lain sebagainya), dinegara-negara anti teroris, orang bernama Arab/Islam dilarang atau diinterogasi lebih dulu untuk masuk ke negara tersebut. Undang-undang Anti Teror melarang untuk memberitahu kepada keluarga tersangka dalam waktu tertentu bagi penahanannya.

Adanya isu hak asasi manusia sejak tahun 1948 rupanya tidak melenyapkan sifat hukum yang anti moral itu. Namun demikian, apabila HAM inheren dengan hukum yang dibuat itu, maka hukum positif akan berubah menjadi hukum positif berkemanusiaan, karena melibatkan moral positif. Artinya, hukum bernuansa moral yang disepakati secara umum sebagai ada. Inilah jiwa dari hukum politik. Tentu saja dalam konteks politik, moral positif dibidang politiklah yang menjadi jiwa hukum politik.

Sehubungan dengan pengaruh politik luar negeri terhadap struktur masyarakat internasional ini, hukum politik berfungsi mengatur/mengendalikan perilaku-perilaku politik internasional negara-negara predominan. Hukum tidak lagi sekedar apa yang diperjanjikan, melainkan hukum memiliki jiwa moral positif sebagai pengaturan perilaku manusia. Contoh yang ada, walaupun banyak pelanggaran terhadapnya, selain Konvensi/Kovenan Internasional dan Peraturan perundang-undangan nasional tentang HAM, adalah hukum humaniter sebagai bagian integral hukum internasional dan HAM. Apabila hukum yang bernuansa HAM dianggap sebagai kemajuan bagi perkembangan paradigma hukum, maka persoalan dasarnya ternyata masih tetap, yaitu cara menegakkannya. Tanpa ada komitmen moral/etik global, maka hukum itupun akan tetap menjadi alat politik entitas predominan. 


\section{Penutup}

Perkembangan situasi dan kondisi internasional tidak lepas dari pengaruh politik luar negeri negara-negara predominan. Hal ini berpengaruh pula terhadap perkembangan hukum, baik dalam skala nasional maupun internasional. Perkembangan mulai dari teori, gerakan, maupun paradigma hukum, belumlah memberikan pengaruh signifikan terhadap perilaku politik predominan negaranegara. Namun demikian manusia sebagai homo iuridicae tetap pada komitmen kemanusiaannya dalam menanggulangi persoalan-persoalan yang timbul dari hubungan-hubungan mereka, baik secara individual maupun secara organisasional. Hal itu terbukti dengan memasukkan kembali nilai-nilai etis ke dalam hukum; dan ini merubah sifat hukum yang positifistik ansich, menjadi hukum positif yang berkemanusiaan. Namun tanpa ada komitmen moral/etik global, maka hukum itupun akan tetap menjadi instrumen politik entitas predominan. Sudah terbukti bagaimana seluruh dokumen HAM dikhianati dengan segala cara untuk dijadikan instrumen politik guna memenuhi kepentingan negara-negara penggagas HAM. 


\section{Daftar Pustaka}

Abdulgani. Kuliah Filsafat Ilmu di Fakultas Pasca Sarjana UNAIR tgl.14 Oktober 1986.

Barker, J. Graig. International Law and International Relation, London: Continuum, 2000.

Black, Donald, Behavior of Law, London: Academic Press, 1976.

Bodenheimer, Edgar. Jurisprudence, The Philosophy and Method of The Law, $3^{\text {rd }}$ printing, Massachusetts: Harvard University Press, 1970.

Boyle, Francis Anthony. World Politics And International Law, Durham: Duke University Press, 1985.

Cass, Deborah Z. Navigating the Newstream: Recent Critical Scholarship in International Law, Nordic Journal of International Law, No.65, Kluwer, The Hague, 1996.

Chand, Hari. Modern Jurisprudence, Kuala Lumpur: International Law Books Services, 1994.

Charter of the UN and Statute of the ICJ, Department of Public Information, UN, New York.

Coubry, Hillaire Mc \& Niegel D. White. Textbook On Jurisprudence, London: Blackstone Press Ltd., 1993.

Effendi, A. Masyhur. Debat Internasional, Memposisikan Aspek Tanggung jawab dalam HAM. Pidato Pengukuhan Gurubesar di Unibraw, 1993.

Jailani, Abdulkadir. ":Hukum Internasional Pasca Perang Irak: Legalisasi Politik Internasional dan Politisasi Hukum Internasional", Indonesian Journal of International Law, vol.2 No.2 Januari 2005.

Juwana, Hikmahanto. Hukum Internasional dalam Konflik Kepentingan Ekonomi Negara Berkembang dan Negara Maju,Bunga Rampai Hukum Ekonomi dan Hukum Internasional, Jakarta: Lentera Hati, 2000.

Koskenniemi, Martti. From Apology to Utopia: The Structure of International Legal Argument, Helsinski: Lakimiesliton Kustannus, 1989.

Kusumaatmadja, Mochtar. Fungsi dan Perkembangan Hukum dalam Pembangunan Nasional, LPHK, FH UNPAD: Binacipta, tanpa tahun. 
Law Cards, Jurisprudence, London: Cavendish Pub., 1997.

Morgenthau, Hans. Politics Among Nations: The Struggle for Power and Peace, Boston: McGraw-Hill Book, 1993.

N. Daldjuni. Hubungan Etika dengan Ilmu, dalam Jujun Suriasumantri (ed.) Ilmu dalam Perspektif, Jakarta: Gramedia, 1984.

Sidharta, Bernard Arief. Refleksi tentang Struktur Ilmu Hukum, Sebuah penelitian tentang fundasi kefilsafatan dan sifat keilmuan hukum sebagai landasan pengembangan ilmu hukumnasional indonesia, Bandung: Mandar Maju, 2000.

Sinha, Surya Prakash. Jurisprudence, Legal Philosophy In A Nut Shell, Minnesota: West Pub. Co., St. Paul, 1993.

Unger, Roberto Mangabeira. Law In Modern Society, Toward a Criticism of Social Theory, New York: The Free Press, 1977.

Unger, Roberto Mangabeira. The Critical Legal Studies Movement, Cambridge: Harvard Univ.Press, 1990. 